\title{
VLASTNOSTI POLYMEREM MODIFIKOVANÝCH ASFALTŮ S PŘÍDAVKEM ZESTÁRLÉHO POJIVA Z R-MATERIÁLU
}

\author{
PROPERTIES OF POLYMER MODIFIED BITUMENS WITH ADDITION \\ OF AGED RAP BINDER
}

\author{
Jiří Sachr ${ }^{*}$ \\ *Jiri.Sachr@vutbr.cz \\ ${ }^{1}$ Vysoké Učení technické v Brně, Fakulta stavební, Veveří 331/95, 60200 Brno
}

\begin{abstract}
Abstrakt
Cílem tohoto příspěvku je popsat vliv přidání různého množství zestárlého pojiva znovuzískaného z R-materiálu na změnu vlastností polymerem modifikovaného asfaltu tř́dy 45/80-65 a polymerem modifikovaného asfaltu označovaného jako 45/80 RC, což je pojivo vhodné pro stmelení asfaltových směsí, které obsahují vysoké množství R-materiálu. Je snahou také zhodnotit změny vlastností těchto směsných asfaltových pojiv způsobených laboratorní simulací stárnutí metodou RTFOT (rolling thin film oven test) a PAV (pressure ageing vessel). Pro znovuzískání zestárlých pojiv je využit R-materiál obsahující nemodifikované asfaltové pojivo i R-materiál získaný z asfaltové směsi, u které lze předpokládat, že obsahuje polymerem modifikovaný asfalt. Zestárlé pojivo získané z R-materiálu je do čerstvého pojiva dávkováno v množství $0 \%, 15 \%, 30 \%$ a $50 \%$.
\end{abstract}

\section{Klíčová slova}

R-materiál, PMB, PMB RC, stárnutí asfaltového pojiva, RTFOT, PAV, penetrace jehlou, bod měknutí, vratná duktilita

\begin{abstract}
The aim of this paper is to describe the effect of adding different amounts of aged binder recovered from RAP on the change in properties of polymer modified bitumen 45/80-65 and polymer modified bitumen referred to as 45/80 RC, which is a binder suitable for cementing asphalt mixtures containing high amounts of RAP. It is also an effort to evaluate the changes in properties of these blended asphalt binders caused by laboratory simulation of aging by rolling thin film oven test (RTFOT) and pressure aging vessel (PAV). Both RAP containing unmodified asphalt binder and RAP obtained from an asphalt mixture that can be assumed to contain polymer modified bitumen are used to recover the aged binders. The aged binder obtained from the RAP is dosed into the fresh binder at $0 \%, 15 \%, 30 \%$ and $50 \%$.
\end{abstract}

Key words

RAP, PMB, PMB RC, asphalt binder aging, RTFOT, PAV, needle penetration, softening point, elastic recovery

\section{1 ÚVOD}

Během posledních desetiletí dramaticky vzrostl počet vozidel na obyvatele i zatížení vozovek od dopravy. Toto náhlé přetížení zkrátilo životnost netuhých (asfaltových) vozovek a zvýšilo náklady na údržbu. Rovněž se zvýšila bezpečnostní rizika pro uživatele těchto přetížených komunikací. Aby se omezilo zhoršování kvality silniční sítě, bylo nutno zlepšit kvalitu a únosnost netuhých vozovek. Toho bylo dosaženo přidáním polymeru do asfaltového pojiva. Od svého zavedení získaly polymerem modifikované asfalty na významu během druhé poloviny dvacátého století a nyní hrají zásadní roli v oblasti silničního stavitelství, zejména u vozovek s vysokou tř́dou dopravního zatížení [1].

V současnosti vozovky obsahující asfaltové směsi stmelené polymerem modifikovanými asfalty stále více dosahují konce své životnosti a dochází k tomu, že R-materiál bude často obsahovat polymerem modifikovaný asfalt. I když recyklace asfaltové směsi je dnes běžnou praxí, dosud neexistuje široce akceptovaná technika recyklace asfaltových směsí stmelených polymerem modifikovaným asfaltem. Pro obnovení reologických 
vlastností zestárlého asfaltového pojiva z R-materiálu se používají tzv. oživovací př́sady, měkký asfalt, nebo speciálně navržená modifikovaná pojiva určená pro účel recyklace (tzv. PMB RC) [2].

Asfaltové pojivo jako organický materiál podléhá degradačním procesům, které jsou způsobeny především vlivem působení vzdušného kyslíku, změnou okolních teplot nebo vlivem ultrafialového záření. Vzhledem k faktu, že asfaltové vozovky slouži svému účelu často i několik desítek let, je hodnocení stárnutí asfaltového pojiva jednou z klíčových vědních disciplín v silničním stavitelství. Následkem změny vlastností asfaltového pojiva v čase totiž často dochází ke vzniku poruch asfaltových vozovek. Stárnutí asfaltových pojiv v laboratoři se nejčastěji simuluje metodami RTFOT (krátkodobé stárnutí pojiva při výrobě asfaltové směsi na obalovně) a následně PAV (dlouhodobé stárnutí pojiva ve vrstvě asfaltové směsi umístěné na vozovce po dobu cca 7 až 10 let) [3].

Vlastnosti zestárlých asfaltových směsí obsahujících R-materiál jsou poměrně dosti zmapovány a popsány $\mathrm{v}$ různých odborných publikacích. Oproti tomu vlastnosti samotných asfaltových pojiv smísených s pojivy z R-materiálu obsahujícího modifikovaná či nemodifikovaná asfaltová pojiva již zdaleka nejsou tak často publikována. Stejně jako se vyvíjí nové typy asfaltových směsí, tak se rovněž vyvíjí i asfaltová pojiva, jejichž vlastnosti jsou čím dál komplexnější. Mezi tato asfaltová pojiva patří např́íklad pojiva typu PMB RC. Rovněž o těchto specifických pojivech je v odborné literatuře uvedeno doposud jen velice omezené množství informací.

Polymerem modifikované asfalty typu PMB RC jsou speciální modifikované asfalty, které jsou vhodné pro stmelení asfaltových směsí obsahujících zvýšené dávkování R-materiálu. Požadavky a zkušební metody asfaltových pojiv typu PMB RC jsou uvedeny v ČSN EN 14023 a ČSN $657222-1$ a zejména ve změně Z1 normy ČSN 65 7222-1. Oproti obvyklým polymerem modifikovaným asfaltům má PMB RC zpravidla vyšší stupeň modifikace. Asfaltové pojivo typu PMB RC může mít př́znivý vliv na zvýšení bodu měknutí (vlivem vyššího stupně modifikace), snížení bodu lámavosti a obnovení elasticity zestárlého asfaltového pojiva v R-materiálu [4].

\section{POUŽITÉ MATERIÁLY}

Pro přípravu směsí asfaltových pojiv byly vybrány dva R-materiály, přičemž R-materiál A obsahuje modifikované asfaltové pojivo a R-materiál B obsahuje pojivo nemodifikované. Pro výrobu směsných pojiv bylo použito asfaltové pojivo výrobce OMV Starfalt PMB 45/80-65 a PMB 45/80 RC. Směsná pojiva byla vyrobená v poměrech dávkování, uvedených v Tab. 1.

Tab 1. Poměry dávkování asfaltových pojiv při výrobě směsných pojiv.

$\begin{array}{ll}100 \% 45 / 80-65+0 \% \text { pojiva z R-materiálu A } & 100 \% 45 / 80-65+0 \% \text { pojiva z R-materiálu B } \\ 85 \% 45 / 80-65+15 \% \text { pojiva z R-materiálu A } & 85 \% 45 / 80-65+15 \% \text { pojiva z R-materiálu B } \\ 70 \% 45 / 80-65+30 \% \text { pojiva z R-materiálu A } & 70 \% 45 / 80-65+30 \% \text { pojiva z R-materiálu B } \\ 50 \% 45 / 80-65+50 \% \text { pojiva z R-materiálu A } & 50 \% 45 / 80-65+50 \% \text { pojiva z R-materiálu B } \\ 100 \% 45 / 80 \text { RC + } 0 \% \text { pojiva z R-materiálu A } & 100 \% 45 / 80 \mathrm{RC}+0 \% \text { pojiva z R-materiálu B } \\ 85 \% 45 / 80 \mathrm{RC}+15 \% \text { pojiva z R-materiálu A } & 85 \% 45 / 80 \mathrm{RC}+15 \% \text { pojiva z R-materiálu B } \\ 70 \% 45 / 80 \mathrm{RC}+30 \% \text { pojiva z R-materiálu A } & 70 \% 45 / 80 \mathrm{RC}+30 \% \text { pojiva z R-materiálu B } \\ 50 \% 45 / 80 \mathrm{RC}+50 \% \text { pojiva z R-materiálu A } & 50 \% 45 / 80 \mathrm{RC}+50 \% \text { pojiva z R-materiálu B }\end{array}$

\section{POUŽITÉ ZKUŠEBNÍ METODY}

Pro zjištění laboratorních vlastností asfaltových pojiv a jejich směsí byly použity následující postupy:

\section{Extrahování pojiva z R-materiálu}

Před započetím provádění laboratorních zkoušek je potřeba znovuzískat asfaltové pojivo z R-materiálu. Extrakce pojiva se řídí normou ČSN EN 12697-1: Asfaltové směsi - Zkušební metody - Č́st 1: Obsah rozpustného pojiva [5]. K oddělení pojiva z R-materiálu se použije tetrachlorethylen neboli perchlorethylen. R-materiál se v uzavíratelné nádobě zalije rozpouštědlem a za občasného promíchání se nechá rozpustit. Pro oddělení kameniva se obsah nádoby vylije přes síta s velikostí ok $2 \mathrm{~mm}$ a $0,063 \mathrm{~mm}$ do průtokové odstředivky. Odstředěný roztok se vypustí do připravené nádoby a pojivo se znovu získá vakuovou destilací podle normy ČSN EN 12697-3+A1: Asfaltové směsi - Zkušební metody pro asfaltové směsi za horka - Č́st 3: Znovuzískání extrahovaného pojiva: Rotační vakuové destilační zařizení [6]. 


\section{Míchání směsí pojiv}

Směsi asfaltových pojiv (polymerem modifikovaný asfalt třídy 45/80-65 resp. 45/80 RC a pojivo znovuzískané z obou R-materiálů) byly namíchány v přesně určených poměrech. Pojiva byla nejprve v laboratorní sušárně rozehřátá na teplotu $180^{\circ} \mathrm{C}$, důkladně homogenizována intenzivním promícháním špachtlí a následně dávkována do jednotlivých plechovek se současným intenzivním promícháním v poměrech 45/80-65 + $(0 \%, 15 \%, 30 \%$ a $50 \%)$ R-materiálu A, a 45/80 RC + (0\%, $15 \%, 30 \%$ a $50 \%)$ R-materiálu B.

\section{Stárnutí směsí asfaltových pojiv}

Směsná asfaltová pojiva byla zestárlá pomocí laboratorní simulace stárnutí asfaltových pojiv metodou RTFOT. Stárnutí probíhalo v souladu s normou ČSN EN 12607-1: Asfalty a asfaltová pojiva - Stanovení odolnosti proti stárnutí vlivem tepla a vzduchu - Č́st 1: Metoda RTFOT [7]. Takto zestárlá pojiva byla dále podrobena simulaci dlouhodobého stárnutí prostřednictvím prrístroje PAV. Postup stárnutí byl v souladu s normou ČSN EN 14769: Asfalty a asfaltová pojiva - Urychlené dlouhodobé stárnutí v tlakové nádobě (PAV) [8], přičemž byla zvolena teplota $100^{\circ} \mathrm{C}$ a doba stárnutí 20 hodin.

\section{Penetrace jehlou podle ČSN EN 1426 [9]}

Zkouška se provádí v penetrometru pomocí penetrační jehly z tvrzené, leštěné a korozivzdorné oceli při konstantní teplotě vodní lázně $25^{\circ} \mathrm{C}$. Při zkoušce se nastaví zkušební jehla zatížená celkovým závažím $100 \mathrm{~g}$ tak, aby se její hrot dotýkal vzorku pojiva. Vytáruje se nulová poloha jehly a na dobu $5 \mathrm{~s}$ se uvolní držák jehly. Zaznamená se hloubka vpichu penetrační jehly jako hodnota penetrace v desetinách milimetru (penetrační jednotky). Postup se zopakuje na třech místech vzorku pojiva. Výsledkem je průměr z těchto tř́i měření zaokrouhlený na celé číslo.

\section{Bod měknutí podle ČSN EN 1427 [10]}

Zkouškou bodu měknutí se zjišt'uje chování asfaltových pojiv při vyšších teplotách. Při zvyšování teploty asfaltové pojivo v závislosti na své viskozitě pozvolně přechází do tekutého stavu. Bod měknutí určený metodou kroužek a kulička je teplota, při níž asfaltové pojivo v závislostí na rostoucí teplotě změkne natolik, že ocelová kulička o průměru $9,5 \mathrm{~mm}$ pronikne vrstvou pojiva a protáhne ji do hloubky $(25 \pm 0,4)$ mm pod spodní okraj prstenu.

Při zahřívání se pozorují oba dílčí zkušební vzorky a v okamžiku, kdy změklý vzorek protažený tlakem kuličky přeruší laserový paprsek zkušebního zařízení, odečte se teplota s přesností odpovídající dělení stupnice. Výsledná hodnota bodu měknutí, stanovená zkouškou kroužek a kulička, je aritmetický průměr ze dvou dílčích měření.

\section{Vratná duktilita podle ČSN EN 13398 [11]}

Zkušební těleso z asfaltového pojiva se protahuje při konstantní teplotě vodní lázně $25{ }^{\circ} \mathrm{C}$ předepsanou rychlostí $50 \mathrm{~mm} / \mathrm{min}$ na délku $200 \mathrm{~mm}$. Takto získané vlákno asfaltového pojiva se uprostřed přestřihne, čímže se získají dvě poloviny vlákna (polovlákna). Díky elastickým vlastnostem pojiv mají polovlákna tendenci navrácení se do původního tvaru (zkracovat se). Po uplynutí 30 minut se měří zkrácení polovláken a vyjadřuje se jako procento z délky protažení.

\section{VÝSLEDKY}

Na směsných asfaltových pojivech byly provedeny laboratorní zkoušky stanovující penetraci jehlou, bod měknutí a vratnou duktilitu. Tyto zkoušky byly prováděny na nezestárlých pojivech a stejně tak na pojivech zestárlých pomocí metod RTFOT a PAV. Veškeré tyto výsledky jsou graficky znázorněny a popsány níže v této kapitole.

\section{Penetrace jehlou}

Výsledky průměrných hodnot penetrace jehlou asfaltových pojiv znovuzískaných z R-materiálů obsahujících modifikovaný i nemodifikovaný asfalt jsou uvedeny v Tab. 2. Výsledky průměrných hodnot penetrace jehlou polymerem modifikovaných asfaltů 45/80-65 a 45/80 RC, směsných pojiv a směsných pojiv po RTFOT a PAV jsou uvedeny na Obr. 1 a Obr. 2. Hodnoty penetrace jehlou pojiv získaných z R-materiálů jsou srovnatelné. Mírně vyšší penetraci dosahuje pojivo získané z R-materiálu A, jenž obsahuje modifikované pojivo. Penetrace polymerem modifikovaných asfaltů 45/80-65 a 45/80 RC vyhovuje požadavkům normy ČSN $657222-1$ včetně 
změny Z1, přičemž hodnota penetrace pojiva třídy 45/80 RC je vyšší o 14 penetračních jednotek oproti penetraci pojiva třídy 45/80-65. Po simulaci stárnutí je tento rozdíl 5 penetračních jednotek.

Tab 2. Penetrace jehlou stanovená na pojivech získaných z R-materiálů.

\begin{tabular}{cc}
\hline Označení & Penetrace jehlou [0,1 mm] \\
\hline R-materiál A & 16 \\
R-materiál B & 14 \\
\hline
\end{tabular}

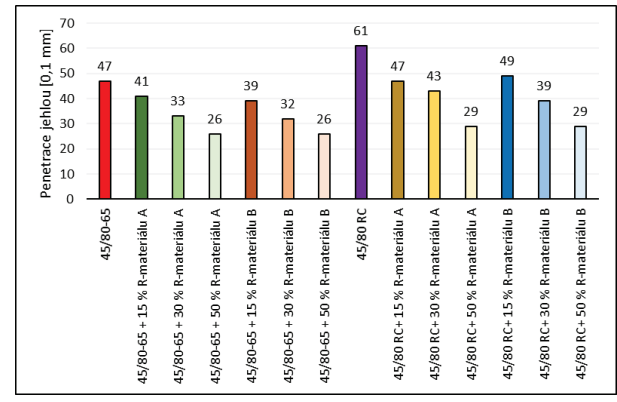

Obr. 1 Penetrace jehlou směsných asfaltových pojiv.

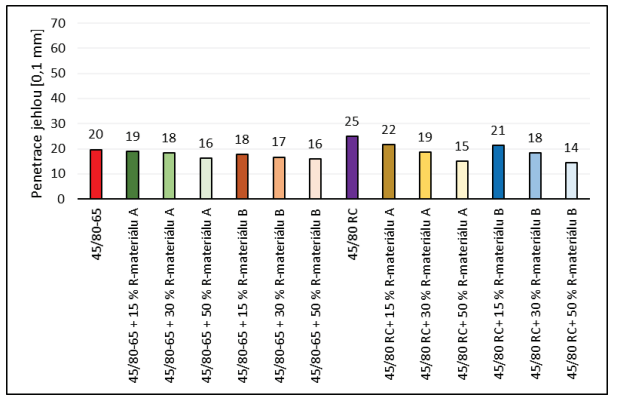

Obr. 2 Penetrace jehlou směsných asfaltových pojiv zestárlých metodou RTFOT a PAV.

Z Obr. 1 je patrné, že hodnoty penetrace jehlou se po přidání pojiva z R-materiálu k novému čerstvému pojivu snižují. To znamená, že u namíchaných směsí pojiv se s vyšším podílem pojiva získaného z R-materiálu zvyšuje viskozita. Na Obr. 2 je jasně vidět, že u pojiv po simulaci dlouhodobého stárnutí klesla penetrace jehlou o více než polovinu.

\section{Bod měknutí}

Výsledky průměrných hodnot bodu měknutí asfaltových pojiv znovuzískaných z R-materiálů obsahujících modifikovaný i nemodifikovaný asfalt jsou uvedeny v Tab. 3. Výsledky průměrných hodnot bodu měknutí polymerem modifikovaných asfaltů 45/80-65 a 45/80 RC, směsných pojiv a směsných pojiv po RTFOT a PAV jsou uvedeny na Obr. 3 a Obr. 4. Hodnota bodu měknutí pojiva získaného z R-materiálu A obsahujícího modifikovaný asfalt je o 5,7 ${ }^{\circ} \mathrm{C}$ vyšší, než bod měknutí pojiva získaného z R-materiálu $\mathrm{B}$ obsahujícího nemodifikovaný silniční asfalt. Bod měknutí polymerem modifikovaných asfaltů 45/80-65 a 45/80 RC vyhovuje požadavkům normy ČSN 65 7222-1 včetně změny Z1, přičemž hodnota bodu měknutí pojiva 45/80 RC je vyšší téměř o $3{ }^{\circ} \mathrm{C}$ než bod měknutí pojiva třídy 45/80-60. Po simulaci stárnutí je tento rozdíl $1,5^{\circ} \mathrm{C}$.

Tab 3. Bod měknutí stanovený na pojivech získaných z R-materiálů

\begin{tabular}{cc}
\hline Označení & Bod měknutí $\left[{ }^{\circ} \mathbf{C}\right]$ \\
\hline R-materiál A & 74,0 \\
R-materiál B & 68,4 \\
\hline
\end{tabular}

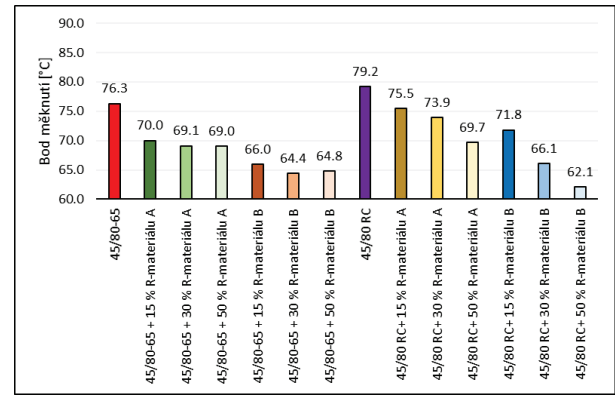

Obr. 3 Bod měknutí směsných asfaltových pojiv.

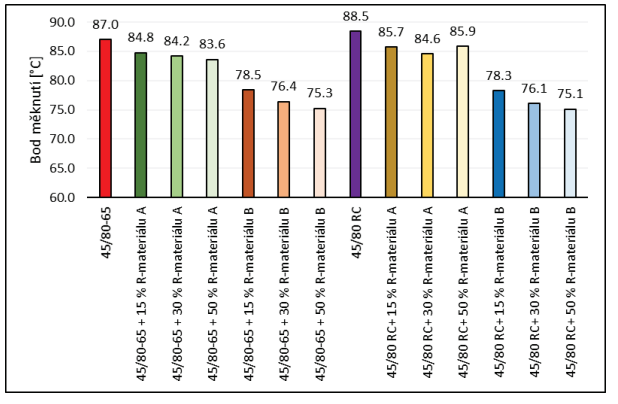

Obr. 4 Bod měknutí směsných asfaltových pojiv zestárlých metodou RTFOT a PAV. 
Z Obr. 3 je patrné, že hodnoty bodu měknutí se po přidání pojiva z R-materiálu k novému čerstvému pojivu sníží. To je pravděpodobně způsobeno "naředěním" modifikačního systému, obsaženého v čerstvých polymerem modifikovaných asfaltech, zestárlými pojivy z R-materiálů. Hodnoty bodu měknutí u směsných asfaltových pojiv s obsahem 50 \% pojiva z R-materiálu jsou ve všech prŕípadech nižší, než samotný 100 \%-ní R-materiál. To je velice překvapivý výsledek, neodpovídající údajům z odborné literatury a tento jev by bylo vhodné ověrit dalším výzkumem.

Na Obr. 4 je jasně patrný nárust hodnot teploty bodu měknutí. To je zapříčiněno tím, že během stárnutí metodou RTFOT a PAV asfaltová pojiva podléhají degradaci a oxidují. Zestárlé pojivo je tedy tvrdší než pojivo nezestárlé a k jeho protažení pod zatížením kuličky je zapotřebí daleko vyšší teploty.

\section{Penetrační index}

$\mathrm{Z}$ výsledků penetrace a bodu měknutí je možné stanovit penetrační index $\left(\mathrm{I}_{\mathrm{p}}\right)$, jako indikátor teplotní citlivosti asfaltového pojiva. Penetrační index se vypočítá z hodnoty penetrace jehlou př́ teplotě $25{ }^{\circ} \mathrm{C}$ (Pen) a z hodnoty bodu měknutí $\left(\mathrm{t}_{\mathrm{kk}}\right)$, viz rovnice níže. Výpočet je založen na hypotéze Pfeiffera a Van Doormaela, kdy se předpokládá, že při teplotě bodu měknutí je hodnota penetrace jehlou asfaltového pojiva rovna $800(0,1 \mathrm{~mm})$.

$$
I_{p}=\frac{20 \cdot t_{k k}+500 \cdot \log (\text { Pen })-1952}{t_{k k}-50 \cdot \log (\text { Pen })+120}
$$

Pomocí penetračního indexu lze obecně asfaltová pojiva rozdělit na multigrádové a oxidované, které mají penetrační index kladný a dále na silniční a destilační asfalty, které mají penetrační index záporný. S růstem penetračního indexu přechází asfalt ze "sol" typu na "sol-gel" typ. Obecně lze říct, že asfalt s vyšším penetračním indexem má lepší viskoelastické vlastnosti. Hodnota penetračního indexu se pohybuje v rozmezí -3 (velmi citlivé na teplotu) a +7 (téměř žádná teplotní citlivost).

Výsledky penetračního indexu asfaltových pojiv znovuzískaných z R-materiálů obsahujících modifikovaný i nemodifikovaný asfalt jsou uvedeny v Tab. 4. Výsledky penetračního indexu polymerem modifikovaných asfaltů 45/80-65 a 45/80 RC, směsných pojiv a směsných pojiv po RTFOT a PAV jsou uvedeny na Obr. 5 a Obr. 6 .

Tab 4. Penetrační index stanovený na pojivech získaných z R-materiálů

\begin{tabular}{cc}
\hline Označení & Penetrační index [-] \\
\hline R-materiál A & 0,92 \\
R-materiál B & $-0,11$ \\
\hline
\end{tabular}

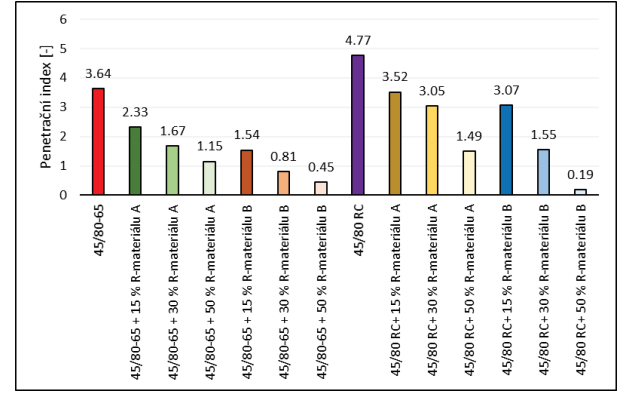

Obr. 5 Penetrační index směsných asfaltových pojiv.

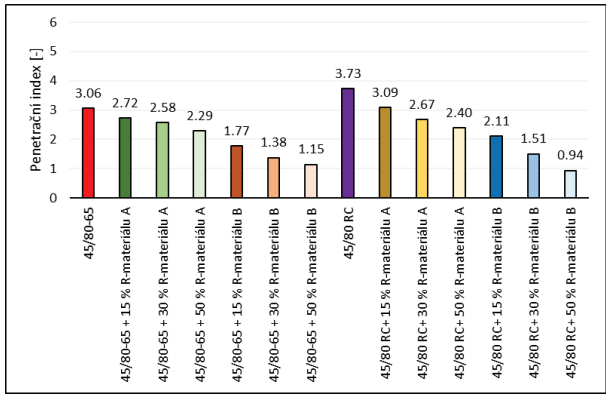

Obr. 6 Penetrační index směsných asfaltových pojiv zestárlých metodou RTFOT a PAV.

Z Obr. 5 je patrné, že s rostoucím obsahem pojiva získaného z R-materiálu klesá hodnota penetračního indexu směsného pojiva. Nejvyšších hodnot penetračního indexu (lepší viskoelastické vlastnosti a nižší teplotní citlivost) dosahoval polymerem modifikovaný asfalt třídy 45/80 RC, který byl následován pojivem třídy 45/80-60. Vyšší (lepší) hodnoty penetračního indexu dosahovaly směsi pojiv obsahující znovuzískané pojivo z R-materiálu A, u kterého se předpokládalo, že obsahuje modifikované asfaltové pojivo. Naopak nižší hodnoty penetračního indexu dosahovaly směsi pojiv obsahující znovuzískané pojivo z R-materiálu B, který obsahoval nemodifikační silniční asfalt. Rovněž vyšších hodnot dosahovaly většinou směsi pojiv obsahující polymerem modifikované asfaltové pojivo třídy 45/80 RC. To prokazuje výhodné vlastnosti pojiv typu "RC" při jejich mísení se zestárlými pojivy obsaženými v R-materiálech. 
Z Obr. 6 je zřejmé, že u některých směsných pojiv penetrační index stoupnul, naopak u čistých pojiv index klesnul. To je zapříčiněno tím, že zestárlá pojiva jsou znatelně tvrdší než pojiva nezestárlá a mají tedy nižší penetraci a vyšší bod měknutí. To se projeví ve výpočtu penetračního indexu.

\section{Vratná duktilita}

Výsledky hodnot vratné duktility polymerem modifikovaných asfaltů 45/80-65 a 45/80 RC a směsí těchto pojiv s pojivy znovuzískanými z R-materiálu A a R-materiálu B jsou zobrazeny na Obr. 7 a Obr. 8. Hodnota vratné duktility polymerem modifikovaného asfaltu tř́ídy 45/80 RC je o $6,5 \%$ vyšší než hodnota vratné duktility pojiva třídy 45/80-65. To znamená, že pojivo typu "RC" dosahuje vyššího stupně polymerní modifikace. Hodnoty vratné duktility polymerem modifikovaných asfaltů 45/80-65 a 45/80 RC vyhovují požadavkům normy ČSN 65 7222-1 včetně změny Z1.

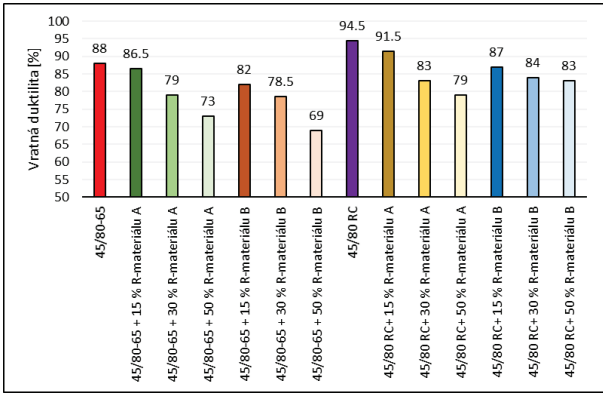

Obr. 7 Vratná duktilita směsných asfaltových pojiv.

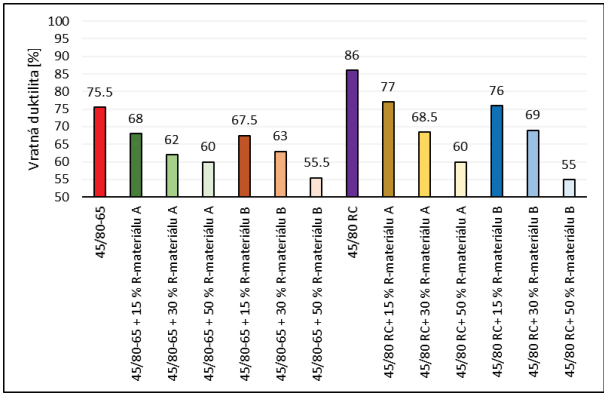

Obr. 8 Vratná duktilita směsných asfaltových pojiv zestárlých metodou RTFOT a PAV.

Z Obr. 7 a Obr. 8 je patrné, že s rostoucím obsahem pojiva získaného z R-materiálu hodnota vratné duktility klesá. Směsi asfaltových pojiv obsahující pojivo získané z R-materiálu A, u kterého se předpokládá obsah polymerem modifikovaného pojiva, dosahovaly většinou vyšší hodnoty vratné duktility, než směsi obsahující pojivo z R-materiálu $\mathrm{B}$, který je stmelen nemodifikovaným silničním asfaltem. Vyšší hodnoty vratné duktility byly vždy dosaženy v prrípadě směsí pojiv obsahujících polymerem modifikovaný asfalt třídy 45/80 RC oproti směsím s obsahem pojiva trrídy 45/80-65. To opět dokazuje, že pojiva typu "RC" je vhodné přidávat do směsí s vyšším obsahem R-materiálu.

Z Obr. 8 je zřejmé, že hodnota vratné duktility u pojiv zestárlých pomocí metody RTFOT a PAV v porovnání s nezestárlými pojivy klesá. To je zapříčiněno tím, že už tak "naředěná" polymerní modifikace ve směsných pojivech se dále poškozuje vlivem degradačních procesů probíhajících během stárnutí metodou RTFOT a PAV.

\section{ZÁV̌̌R}

Z výsledků vyplývá, že přidáním zestárlého asfaltového pojiva z R-materiálu do nového polymerem modifikovaného pojiva typu 45/80-65 a typu 45/80 RC se zvýší viskozita směsného pojiva. To bylo prokázáno snížením hodnoty penetrace jehlou. S rostoucím obsahem pojiva získaného z R-materiálu rovněž klesá hodnota penetračního indexu směsi pojiva a zhoršuje se hodnota vratné duktility. Pokud ovšem bylo použito pojivo získané z R-materiálu stmeleného modifikovaným pojivem, zhoršení těchto vlastností nebylo tak patrné jako při použití pojiva z R-materiálu obsahujícího nemodifikovaný silniční asfalt. Rovněž při použití pojiva typu "RC" nedošlo k tak výraznému ovlivnění chování směsných pojiv oproti směsím, ve kterých byl obsažen standardní polymerem modifikovaný asfalt 45/80-65. To potvrzuje předpoklad, že pojivo typu "RC" je vhodné pro stmelení asfaltových směsí s vysokým obsahem R-materiálu.

Zajímavé výsledky byly naměřeny při provádění zkoušky bodu měknutí, jelikož po přidání pojiv získaných z R-materiálů došlo ke snížení bodu měknutí směsných pojiv. To je pravděpodobně způsobeno "naředěním" modifikačního systému obsaženého $\mathrm{v}$ čerstvých polymerem modifikovaných asfaltech zestárlými pojivy z R-materiálů. Překvapivé bylo, že se hodnoty bodu měknutí směsí pojiv neumístily mezi bodem měknutí pojiv, ze kterých byly tyto směsi vyrobeny. Velice často došlo k poklesu hodnoty bodu měknutí směsi pojiva pod bod měknutí samotného pojiva získaného z R-materiálu. To je velice překvapivý výsledek neodpovídající údajům z odborné literatury a tento jev by bylo vhodné ověřit dalším výzkumem.

U směsí asfaltových pojiv, která prošla simulací laboratorního stárnutí metodou RTFOT a PAV byly zaznamenány totožné tendence jako u směsí pojiv nezestárlých. Jedinou výjimkou je penetrační index, který 
u zestárlých pojiv v mnoha př́ípadech vzrostl. To je zapříčiněno tím, že zestárlá pojiva jsou znatelně tvrdší než pojiva nezestárlá a mají tedy nižší penetraci a vyšší bod měknutí. To se projeví ve výpočtu penetračního indexu.

\section{Poděkování}

Př́́spěvek vznikl s podporou projektu FAST-J-21-7525 „Vlastnosti polymerem modifikovaných asfaltů s obsahující pojiva získaná z R-materiálu“ podporovaného Vysokým učením technickým v Brně a projektu CK01000158 „Využití vyšších množství R-materiálu v asfaltových směsích s asfaltovými pojivy typu PmB“ podporovaného Technologickou agenturou České republiky.

\section{Použité zdroje}

[1] POLACCO, Giovanni, Sara FILIPPI, Filippo MERUSI a George STASTNA. A review of the fundamentals of polymer-modified asphalts: Asphalt/polymer interactions and principles of compatibility. Colloid and Interface Science. 2015, 2015(224), 72-112. ISSN 0001-8686.

[2] ALI, Ayman, Yusuf MEHTA, Aaron NOLAN, Caitlin PURDY a Thomas BENNET. Investigation of the impacts of aging and RAP percentages on effectiveness of asphalt binder rejuvenators. Construction and Building Materials. 2016, 2016(110), 211-217. ISSN 0950-0618.

[3] Comparative Study of RTFOT and PAV Aging Simulation Laboratory Tests. Transportation Research Record: Journal of the Transportation Research Board. 1998, 1638(1), 56-63. ISSN 0361-1981. Dostupné z: doi:10.3141/1638-07

[4] Polymer modified bitumen: Properties and characterisation. 1. UK: TJI Digital, 2011. ISBN 978-0-85709$372-1$.

[5] ČSN EN 12697-1. Asfaltové směsi - Zkušební metody - Část 1: Obsah rozpustného pojiva. 01.10.2020. Praha: Česká technická norma (ČSN), 2020.

[6] Asfaltové směsi - Zkušební metody - Část 3: Znovuzískání extrahovaného pojiva: Rotační vakuové destilační zařízení. 01.03.2021. Praha: Česká technická norma (ČSN), 2021.

[7] Asfalty a asfaltová pojiva - Stanovení odolnosti proti stárnutí vlivem tepla a vzduchu - Cást 1: Metoda RTFOT. 01.05.2015. Praha: Česká technická norma (ČSN), 2015

[8] Asfalty a asfaltová pojiva - Urychlené dlouhodobé stárnutí v tlakové nádobě (PAV). 01.12.2012. Praha: Česká technická norma (ČSN), 2012.

[9] Asfalty a asfaltová pojiva - Stanovení penetrace jehlou. 01.12.2015. Praha: Česká technická norma (ČSN), 2015.

[10] Asfalty a asfaltová pojiva - Stanovení bodu měknutí - Metoda kroužek a kulička. 01.12.2015. Praha: Česká technická norma (ČSN), 2015.

[11] Asfalty a asfaltová pojiva - Stanovení vratné duktility modifikovaných asfaltů. 01.08.2018. Praha: Česká technická norma (ČSN), 2018. 